\title{
THE IMPACT OF EMOTIONAL ATTITUDE OF A TEACHER ON THE PRESCHOOLER'S EMOTIONAL DEVELOPMENT
}

\author{
Zainab Akram \\ Assistant Professor, \\ Department of English, SBK Women University, \\ Balochistan, Pakistan \\ Email: zainabmazhar1509@gmail.com \\ Khadija Karim \\ Assistant Professor, \\ Department of Education, SBK Women University, \\ Balochistan, Pakistan \\ Email: khadijakarim17@yahoo.com \\ Hafsa Karim \\ Lecturer, \\ Department of Social Work, University of Balochistan, \\ Balochistan, Pakistan \\ Email: hafsakarim123@yahoo.com
}

\begin{abstract}
Environment, a multi-denotation term, covers the emotional, physical, and the behavioral realms of social setup. The preschool is an inevitably unavoidable step in the academic journey, which is responsible for foundational solidarity, effective learning, career and personality development. Both productive physical environment and behavioral sustainability are required for quality learning. Teacher and pupil relation counts a lot in the emotional development of preschoolers. This research is a qualitative study which focuses on the role teachers' play in the emotional development of preschoolers. For this purpose, 16 checklist items from Godwin (2000) are adapted and distributed among 50 teachers from five various private and semi private schools in Quetta city. Interviews were also conducted from 10 teachers' in order to understand the perceptions of teachers regarding understanding of expression and emotional regulation. The results of questionnaires and interviews were descriptively analyzed. It is found that the emotional attitude of preschool teachers impacts the emotional development of preschoolers. Teachers with expressive care along with effective teaching leads to improved students' emotional development as well as quality learning.
\end{abstract}


KEYWORDS

Teacher-Preschoolers relationship, Quality Learning Environment, Emotions, Attitude, Instruction

\section{INTRODUCTION}

Students' academic and lifelong success mainly depends on the academic behaviors (Borghans et al., 2008). Emotions and personality influence one's learning and thinking capacity. Detailed longitudinal studies have documented the robust prognostic control of incentive and youthful discipline on well-being. Educators have been investigating a wide range of non-researched outcomes like emotional development, disruptive classroom behaviors, and educational achievements. The behavior is sturdier indicator of long-term consequences (Chetty et al., 2011). The noncognitive skills (Duckworth \& Yeager, 2015), are referred to as emotional behaviors also related to academic behaviors (Farrington et al., 2012). Academic actions like motivation, self- control and persistence raises queries about how to best develop these values in children. Teachers substantially have a stronger role in developing academic behaviors. There are many studies proving that poor role of a teacher have lead to an unstable socio-emotional position of students (Robinson et al., 1997). Strong association between a teacher and a student leads to ease and improved future social skills. The teacher-student relationship is as important as compared to peer relationship in an institute (Hartup, 1989).

Teachers affect behaviors of students' academic skills (Ruzek et al., 2014). To distinct teacher influence from broader class effects, i.e. "The combined effect of teachers, peers, and any class-level shock" (Chetty et al., 2011, p. 1596) is a methodological challenge. Studies to explore the precise features of classrooms and instruction performs that are accountable to yield the consequences are very few. The social progress is related with expressive growth, leading additional to care giving relations (Hartup, 1989). Teachers are to be trained about emotional behavior so that they may understand the psychology of emotional development of their students. The undertaken study focuses on teacher-student relation and its effects on emotional development. It also focuses on the perceptions of teachers about the role emotional expressions play during academic hours. It is quite important to know how teachers' emotional attitudes affect students' academic behaviors. Currently, teachers are awarded for improving test scores. However, it is unclear if this approach includes teaching practices to solidify students' emotional development. If the evaluation criteria for teachers include raising test scores without affecting students' emotional behavior. This study focuses to evaluate the non-tested emotional outcomes of teachers and their effects on student's emotional behavior. 


\section{LITERATURE REVIEW}

\section{The pupil's emotional development}

The emotions of a child have life time implications on their development and growth. It has dual functions i.e. motivational and communicative. The motivational aspect deals with the attitude and the communicative aspect deals with their needs or distress like crying and smiling; despite innate emotional abilities, the early care creates the early adaptation of the child (Vaughn et al., 1992). The behavior of a child is affected by the experience and expression of emotions. These behaviors are indicators which suggest others to encourage or retreat social behavior with the child (Denham, 1998). Previous researches show that children can discover, reply and interpret uneasiness in others (Eisenberg et al., 1990). Children also have the ability to acclimatize with cultural regulations for emotional display (Ekman \& Friesman, 1975). The controlling of passions in children is the role efficiently played by teachers (Denham, 1998). The regulation of emotions helps in aids creating relationships. The emotional conduct assessment regulates it to the extent of acceptability. Teachers lead children from help to freedom (Sroufe, 1997). The score of emotional development is certainly dissimilar from their academic achievement on standardized tests, like, feeling right, diligence, determination and resolution, attitude progress, pleasure, willfulness, self-esteem and self-efficacy. These including other factors are found interconnected which display the role of students in improving in academic knowledge and collaborating in informative conditions (Farrington et al. 2012).

The worth of these academic deeds and emotions towards long-term life outcomes have been studied by several researches from different disciplines. In another study Lindqvist and Vaughn et al. (1992) found that, an intricate measure of non-tested undertakings amongst 18 years old was absolutely linked to salaries and negatively associated to job loss. Mueller and Plug (2006) found that earnings of an individual could be told with the help of investigating personality traits like trustworthiness, diligence, extraversion, friendliness and neuroticism. Borghans et al. (2008) have parallel inferences in research reviews. Mindsets and academic behaviors beyond test scores held a long-term importance. Another study discovered that juvenile actions of self-control predicted improved physical fitness and inferior substantial requirement and unlawful actions in adulthood (Moffitt et al., 2011)

\section{The teacher-student relationship}

There are number of issues which are significant in a variety of academic performances and attitudes. It leads to a question of how to inculcate them among children. The teacher is one of the factors responsible for accomplishing academic performances and beyond that successfully. Hence, the role of a teacher is essential in developing nontested results. In fact, the undertaken work concentrates on the role played by the teachers. Besides, the awareness of non-cognitive matters would make educators to 
implement activities in classroom which eventually would help in improving their students' education. Chicago Consortium on School Research stated that classroom activities conducive to students learning performances are vital in students' achievements. The achievements of children are directly related to teachers' attitudes. The link of the teacher and preschoolers leads to the emotional development as well as the development of the communal terms with others (Halberstadt, 1991). This relationship leads to the achievement of child's emotional quality expression, comprehension and regulation. It also leads to the response pattern of the child towards the teacher. This response pattern includes variety of emotional expressions like, insecurity or otherwise; multiple expressions of positivity, negativity and aggression etc (Cassidy, 1994). Teachers' responses lead to children's social and emotional relations with others (Halberstadt, 1991).

Moreover, the role which teachers play in the emotional development of students resulted in the outcomes which were larger than the effects on academic achievement. In another study it was found that expressive teachers had a positive impact on the motivational aspect of the 7th graders. Teachers effects on experiential school behaviors, like grades, absents, delays, grade progression and advancement have been studied by Jackson (2012) and Koedel (2008). The evidence about teachers' role in improving both the academic scores as well as emotional outcomes of the students is somewhat confounded.

\section{The teacher's emotions}

The classroom environment climate (CEC) is of ultimate importance. It is maintained by teachers and it leads to student comfort and positive emotions (Brackett et al., 2011). All of the considerations however, seem to oversight the fact that the emotional status of teachers is as important as the outcomes of students. In one of the metaanalysis shoed that, the positive communication of teachers with students has resulted in a conducive classroom in which students were found to be engaged in learning activities and communication (Roorda et al. 2011). It is usually believed that the teachers who have affecting classroom techniques might also inculcate practices, accountable for radical student consequences. The role of teachers in developing emotional outcomes has been an important expansion in the academic literature. However, to find out, what teachers could do in their classrooms to nurture emotional conducts among students is yet to be explored. Willson (1973) found that during teachers' professional development program, students asked difficult questions from their teachers which proposed to develop difficult questioning methods.

In addition to the development of different questioning methods, researchers became cognizant about the problems teachers face regarding their emotional experiences. In order to provide a conducive environment for the successful outcome of student 
emotional development, teachers needed a positive environment for their emotions as well. They emphasized on their emotional demands as they could not be robotic all the times. The society seems to ignore the fact that teachers need a good environment too for their emotional regulation and expression. Excellence in teaching, be it is of any level, includes the development of emotions as well, claims Postareff and LindblomYlänne (2011). They also said that teachers and their teaching could be comprehended well if knowledge of teachers' emotions, motivation and cognition are achieved. Hargreaves (2000), investigates that student's advancement, reactive and supportive behavior results in teacher's satisfaction and pleasure. Similarly, student idleness, and lack of attentiveness lead to fury and frustration among teachers.

\section{RESEARCH OBJECTIVE}

1. To investigate the implication of the preschoolers' emotional development in their academic career.

2. To investigate the perceptions of teacher's emotional attitude on the preschoolers' emotional development.

3. To explore the perceptions of teachers regarding their expression and emotional attitude for their own emotional and psychological health.

\section{RESEARCH METHODOLOGY}

In this paper, a checklist related to concepts from Godwin (2000) is adapted and distributed among 50 teachers, through stratified sampling, from five various private/semi private schools in Quetta city. These teachers have been teaching for about two years in the preschool section. The distributed questionnaire depicted issues like teachers' attitude with students in relation to emotional development, teacherstudent connections and efficacy towards improving student's effort and contentment in class. The answer for each question is displayed in a separate table depicting the responses in percentages. The checklist is attached in appendix 1. The check list evaluates teacher-student relation based on emotional behavior of both, with five choices in a Lickert scale. Individual interviews were conducted from 10 teachers, randomly selected, from Postareff and Lindblom-Ylänne (2011), to get the better view of teachers' perceptions of their own emotional understanding and regulation.

\section{DATA ANALYSIS}

\section{Checklist}

The checklist was shared with 50 preschool teachers from five different private and semi-private schools of Quetta City. The results are as follows: 


\section{Table:1}

\begin{tabular}{llccccc}
\hline \multicolumn{1}{c}{ Always } & Often & Occasional & Never & $\begin{array}{c}\text { Don't Know } \\
\text { about it }\end{array}$ \\
\hline Q.1 I believe that & 40 & 6 & 4 & 00 & 00 \\
& $\begin{array}{l}\text { teachers are the } \\
\text { role models for } \\
\text { children which } \\
\text { they follow }\end{array}$ & & & & & \\
\hline
\end{tabular}

Table.1 Presents query no. 1 from the checklist. Thus, among 50 participants, 40 believed that teachers to be the role model children are likely to follow. The option of often was selected by 06 teachers, whereas 4 of the teachers choose the option of occasional and none choose the option of never and don't know. The results indicate that most teachers believed to be the role model children are likely to follow, and the implication might be that almost none among the teachers are without the pre-believe of not influencing the preschoolers. By summing up the results into percentage, it is formulated that $80 \%$ of total ticked the option no.1, $12 \%$ went for the option no.2, 08 $\%$ option no. 3 and none went for option no. 4 and 5. It could be implicated that there are teachers who have joined the profession without even understanding the effects and influences of the teachers on the students.

Table. 2

\begin{tabular}{llccccc}
\hline & Always & Often & Occasional & Never & $\begin{array}{c}\text { Don't Know } \\
\text { about it }\end{array}$ \\
\hline Q.2 & $\begin{array}{l}\text { I talk to } \\
\text { children } \\
\text { about } \\
\text { emotions }\end{array}$ & 20 & 11 & 09 & 07 & 03 \\
\hline
\end{tabular}

Table. 2 Presents query no. 2 from the checklist. Among 50 participants, 20 teachers tell the children what are emotions, by contrast 11 teachers choose the option of often, 9 teachers choose the option of occasional and 07 choose the option of never and 03 choose they don't know. The results indicate that a very low \% of teachers have least knowledge about imparting the emotional regulation teaching to students, which might be the result of lack of proper training or lack of understanding the importance of role of emotions in building the characters of pupil. The results indicate that most of the teachers tell the children what are emotions. Presenting the results into percentage, it is formulated that $40 \%$ opted for option no.1, $22 \%$ the option no.2, $18 \%$ went for option no. 3 and $14 \%$ no. 4 and $06 \%$ for 5 . The data shows that less than half of the 
population shows that teachers do understand the importance of emotions and likely to share and discuss it with the pupil.

Table. 3

\begin{tabular}{|c|c|c|c|c|c|c|}
\hline & & Always & Often & Occasional & Never & $\begin{array}{c}\text { Don't Know } \\
\text { about it }\end{array}$ \\
\hline Q.3 & $\begin{array}{l}\text { I tell pupil } \\
\text { about the } \\
\text { acceptable } \\
\text { of } \\
\text { expression } \\
\text { to } \\
\text { teacher }\end{array}$ & 17 & 13 & 10 & 08 & 02 \\
\hline
\end{tabular}

Table.3 Depicted query no. 3 from the checklist. Among 50 participants, 17 teachers tell the students how to express various emotions in acceptable way to the teacher, by contrast 13 teachers choose the option of often, 10 teachers choose the option of occasional and 08 choose the option of never and 02 choose they don't know. The results indicate that most teachers tell the children how to express various emotions in acceptable way. In percentage, $34 \%$ went for option no.1, $26 \%$ option no.2, $20 \%$ option no. 3 and $16 \%$ no. 4 and $04 \%$ for 5 . As comparison of 17 and 02 is a huge gap among teachers' perceptions between imparting the children to express themselves emotionally. It shows many teachers are ware to instruct the pupil about a healthy emotional expression.

Table. 4

\begin{tabular}{llcccc}
\hline & Always & Often & Occasional & Never & $\begin{array}{c}\text { Don't Know } \\
\text { about it }\end{array}$ \\
\hline Q.4 I tell the & 12 & 06 & 03 & 18 & 11 \\
children & & & & & \\
about & & & & & \\
acceptable & & & & \\
& ways of \\
& expressing \\
& several \\
emotions & & & & \\
towards \\
class \\
mate/s.
\end{tabular}

Table. 4 Shows item no. 4 from the checklist. From the 50 participants, 12 teachers tell 
the students how to express various emotions in acceptable way to their peers, by contrast 06 teachers choose the option of often, 03 teachers choose the option of occasional and 18 choose the option of never and 11 choose they don't know. The results indicate that most teachers tell the children how to express various emotions to their peers in acceptable way. It is formulated that $24 \%$ selected option no. $1,12 \%$ no. $2,06 \%$ no. 3 and $36 \%$ no. 4 and $22 \%$ for 5 . The difference between the two extreme categories is very less, and it could be implicated that teachers are not well aware of training in various kinds of emotional expressions in an acceptable way, themselves.

Table. 5

\begin{tabular}{|c|c|c|c|c|c|c|}
\hline & & Always & Often & Occasional & Never & $\begin{array}{l}\text { Don't Know } \\
\text { about it }\end{array}$ \\
\hline Q.5 & $\begin{array}{l}\text { I teach the } \\
\text { children } \\
\text { by } \\
\text { conveying } \\
\text { many } \\
\text { emotions } \\
\text { myself }\end{array}$ & 18 & 12 & 12 & 07 & 01 \\
\hline
\end{tabular}

Table. 5 Presented query no. 5 from the checklist. From 50 participants, 18 teachers teach the students through expressing various emotions herself, by contrast 12 teachers choose the option of often, 12 teachers choose the option of occasional and 07 choose the option of never and 01 choose they don't know. The results indicate that most teachers tell the children how to express various emotions to their peers in an acceptable way. $36 \%$ selected option no. $1,24 \%$ no. $2,24 \%$ supported the option no. 3 and $14 \%$ no. 4 and $02 \%$ for 5 . The high \% reveal that the teachers are aware of expressing their emotions well in front of students in an acceptable way, which is a kind of indirect teaching and instruction.

Table. 6

\begin{tabular}{|c|c|c|c|c|c|c|}
\hline & & Always & Often & Occasional & Never & $\begin{array}{c}\text { Don't Know } \\
\text { about it }\end{array}$ \\
\hline Q.5 & $\begin{array}{l}\text { I suggest } \\
\text { children to } \\
\text { select amid } \\
\text { several } \\
\text { emotional } \\
\text { expressions } \\
\text { in multiple } \\
\text { situations }\end{array}$ & 02 & 00 & 00 & 00 & 48 \\
\hline
\end{tabular}


Table.6 Presents query .6 from the checklist. Among 50 participants, 02 teachers give suggestions to children to choose among various emotional expressions under various situations, by contrast 00 teachers choose the option of often, 00 teachers choose the option of occasional and 00 choose the option of never and 48 choose they don't know. The results indicate that most teachers give suggestions to children to choose among various emotional expressions under various situations. $04 \%$ of ticked option no. 1, 00 $\%$ option no.2, $00 \%$ no. 3 and $00 \%$ no. 4 and $96 \%$ for 5 . The highest $\%$ teachers deny the knowledge to appropriate expression to any emotion, which might indicate dearth of proper training and inclusion of the subject into the teachers training programs and its utilization.

Table. 7

\begin{tabular}{|c|c|c|c|c|c|c|}
\hline & & Always & Often & Occasional & Never & $\begin{array}{l}\text { Don't Know } \\
\text { about it }\end{array}$ \\
\hline Q.7 & $\begin{array}{l}\text { For clarity } \\
\text { and } \\
\text { understanding } \\
\text { of the pupil, I } \\
\text { sometimes } \\
\text { fabricate the } \\
\text { situations, for } \\
\text { a proper } \\
\text { expression of } \\
\text { the prevailing } \\
\text { emotion } \\
\text { stirring in a } \\
\text { child }\end{array}$ & 05 & 00 & 00 & 38 & 07 \\
\hline
\end{tabular}

Table.7 Presents question no. 7 from the checklist. From the 50 participants, 18 teachers in order to make the students understand completely, sometimes create the various situations for the most proper expression of the existing emotional occurring in a child, by contrast 12 teachers choose the option of often, 12 teachers choose the option of occasional and 07 choose the option of never and 01 choose they don't know. The results indicate that most teachers try to make the students understand completely, sometimes create the various situations for the most proper expression of the existing emotional occurring in a child. $10 \%$ of total supported the option no. $1,00 \%$ supported the option no.2, $00 \%$ no.3 and $76 \%$ no. 4 and $14 \%$ for 5 . The minimum difference of opinion between the two extremes indicate that teachers lack the insight of creating situations and fabrication scenario's for a practical teaching of emotional expressions. 


\begin{tabular}{|c|c|c|c|c|c|c|}
\hline \multicolumn{7}{|c|}{ Table.8 } \\
\hline & & Always & Often & Occasional & Never & $\begin{array}{c}\text { Don't Know } \\
\text { about it }\end{array}$ \\
\hline Q.8 & $\begin{array}{l}\text { When a child } \\
\text { exaggerates, } \\
\text { I recreating } \\
\text { and enact the } \\
\text { acceptable } \\
\text { emotion } \\
\text { myself in } \\
\text { same } \\
\text { circumstance }\end{array}$ & 00 & 00 & 00 & 00 & 50 \\
\hline
\end{tabular}

Table. 8 Displayed query no. 8 from the checklist. 00 teachers opine that whenever a child overreacts, the teacher enacts and models with recreating the acceptable emotional display her/his self under the similar situation, by contrast 00 teachers choose the option of often, 00 teachers choose the option of occasional and 00 choose the option of never and 50 choose they don't know. The results indicate that most teachers don't know how to react whenever a child overreacts, the teachers could enact and model with recreating the acceptable emotional display their self under the similar situation. $0 \%$ of total supported the option no.1, $0 \%$ no.2, $0 \%$ no. 3 and $0 \%$ ticked option no.4 and 100\% went with option 5. The highest $\%$ of denial implicates the gap which occurs in teachers knowledge and emotional expression and regulation.

Table. 9

\begin{tabular}{llccccc}
\hline & Always & Often & Occasional & Never & $\begin{array}{c}\text { Don't Know } \\
\text { about it }\end{array}$ \\
\hline Q.9 & $\begin{array}{l}\text { I orally talk } \\
\text { to students } \\
\text { about } \\
\text { various } \\
\text { emotions }\end{array}$ & 12 & 15 & $09+$ & 06 & 08 \\
\hline
\end{tabular}

Table. 9 Shows query no. 9 from the checklist. Among the 50 participants, 12 teachers verbally communicate with students the meaning of various emotions, by contrast 15 teachers choose the option of often, 09 teachers choose the option of occasional and 06 choose the option of never and 08 choose they don't know. The results indicate that most teachers verbally communicate with students the meaning of various emotions. $16 \%$ went for option no. $1,30 \%$ no. $2,36 \%$ option no. $3,12 \%$ no. 4 and $16 \%$ for 5 . Only 12 teachers confirming the conduction of action is a very low percentage for an 
encouraging answer. The reason might be the ignorance of the importance of the action towards self and for the pupil.

Table. 10

\begin{tabular}{llccccc}
\hline & Always & Often & Occasional & Never & $\begin{array}{c}\text { Don't Know } \\
\text { about it }\end{array}$ \\
\hline Q.10 & $\begin{array}{l}\text { I } \\
\text { encourage } \\
\text { children to } \\
\text { express } \\
\text { emotions } \\
\text { of all kinds }\end{array}$ & 13 & 10 & 19 & 00 & 08 \\
\hline
\end{tabular}

Table.10 Presents query no.10 from the checklist that among 50 participants. $26 \%$ opted no. $1,20 \%$ no. $2,38 \%$ no. 3 and none went for no. 4 and $16 \%$ went for no. 5 . The strongly confirmation comes only from 13 teachers, which indeed is not very encouraging amount to go with. The reason might be the low capacity of the teachers regarding the talent and capability to engage the students come up with an outlet through conversation. The teachers need to be inculcated the understanding of necessity of conversation therapy with the pupil as a healthy activity.

Table. 11

\begin{tabular}{llccccc}
\hline & Always & Often & Occasional & Never & $\begin{array}{c}\text { Don't Know } \\
\text { about it }\end{array}$ \\
\hline Q.11 & $\begin{array}{l}\text { I talk to } \\
\text { children } \\
\text { about } \\
\text { distinguishing } \\
\text { amid rash and } \\
\text { tolerable } \\
\text { conduct }\end{array}$ & & 14 & 08 & 05 & 03 \\
\hline
\end{tabular}

Table.11 Presents query no. 11 from the checklist among 50 participants. By summing up the results into percentage, it is formulated that $46 \%$ went for option no.1, $28 \%$ no. $2,16 \%$ ticked option no. 3 and $10 \%$ went for no. 4 and $06 \%$ for 5 . The results shoe almost close to half of population to be accepting the practicality of talking to kids about various behaviors. The high \% depicts the awareness among teachers to be understanding and imparting the knowledge about rash and acceptable attitudes, but the query is still lingering as to if the teachers also consider the sensitivity of situations and the various reasons of pupils to be acting thus. 


\begin{tabular}{|c|c|c|c|c|c|c|}
\hline \multicolumn{7}{|c|}{ Table.12 } \\
\hline & & Always & Often & Occasional & Never & $\begin{array}{c}\text { Don't Know } \\
\text { about it }\end{array}$ \\
\hline Q.12 & $\begin{array}{l}\text { I tell pupil } \\
\text { about } \\
\text { suitable } \\
\text { emotional } \\
\text { show as a } \\
\text { socializing } \\
\text { tool }\end{array}$ & 26 & 12 & 06 & 03 & 03 \\
\hline
\end{tabular}

Table.12 Presents query no.12 from the checklist that among 50 participants. 52\% opted no.1, 24\% no.2, $12 \%$ no. 3 and $06 \%$ went for option no. 4 and $06 \%$ for 5 . Though, more than $50 \%$ teachers show they are well aware of the implication of the question, which is an encouraging sign of their understanding their duties of mentor towards the students.

Table. 13

\begin{tabular}{|c|c|c|c|c|c|c|}
\hline & & Always & Often & Occasional & Never & $\begin{array}{l}\text { Don't Know } \\
\text { about it }\end{array}$ \\
\hline Q.13 & $\begin{array}{l}\text { I tell pupil } \\
\text { the } \\
\text { emotional } \\
\text { information } \\
\text { for many } \\
\text { emotional } \\
\text { occasions }\end{array}$ & 05 & 04 & 08 & 23 & 10 \\
\hline
\end{tabular}

Table. 13 Presented query no. 13 from the checklist for 50 participants. $10 \%$ opted no. $1,08 \%$ opted no. $2,16 \%$ opted no. 3 and $46 \%$ opted no. 4 and $20 \%$ for 5 . The major portion have opted either for never or that they do not have any information about the tactics, which shows the lack of understanding on part of teachers about the importance of the process on discussion and debate with the students.

Table. 14

\begin{tabular}{llccccc}
\hline & Always & Often & Occasional & Never & $\begin{array}{c}\text { Don't Know } \\
\text { about it }\end{array}$ \\
\hline Q.14 & $\begin{array}{l}\text { I explicitly } \\
\text { react with } \\
\text { emotional } \\
\text { behavior }\end{array}$ & 09 & 08 & 18 & 09 & 06 \\
\hline \hline
\end{tabular}


for pupil to

understand

emotions

Table.14 Presented query no.14. It is found that $18 \%$ of total supported the option no.1, $16 \%$ opted no. $2,36 \%$ no. 3 and $18 \%$ supported option no. 4 and $12 \%$ for 5 . The minimum difference of opinion indicates the lack of perhaps understanding clarity of the question, as most teachers might not have experienced the abrupt display of positive reactions to various reactions of the pupil.

Table. 15

\begin{tabular}{|c|c|c|c|c|c|c|}
\hline & & Always & Often & Occasional & Never & $\begin{array}{c}\text { Don't Know } \\
\text { about it }\end{array}$ \\
\hline Q.14 & $\begin{array}{l}\text { I support } \\
\text { the } \\
\text { emotional } \\
\text { display of } \\
\text { the pupil } \\
\text { with } \\
\text { reward or } \\
\text { by } \\
\text { punishing }\end{array}$ & 28 & 11 & 05 & 00 & 06 \\
\hline
\end{tabular}

Table. 15 Presented query no. 15 . it is shown that $56 \%$ opted no. $1,22 \%$ no. $2,10 \%$ went for option no. 3 and none selected option no. 4 and $12 \%$ for 5 . The high percentage of teachers responding to the question indicate the insight and awareness of significance of incentive and penalty by the teachers on the performance of pupil.

Table. 16

\begin{tabular}{llcccc}
\hline & Always & Often & Occasional & $\begin{array}{c}\text { Never } \\
\text { Q.14't Know } \\
\text { about it }\end{array}$ \\
\hline $\begin{array}{l}\text { I endure } \\
\text { the }\end{array}$ & 21 & 16 & 06 & 02 & 05 \\
negative \\
behavior of \\
$\begin{array}{l}\text { a child as } \\
\text { effective } \\
\text { and } \\
\text { concerned }\end{array}$ & & & & & \\
\hline
\end{tabular}

Table.16 Presented query no. 16 . It is found that $42 \%$ opted no. $1,32 \%$ no. $2,12 \%$ went 
for no. 3 and $04 \%$ no. 4 and $10 \%$ for 5 . The highest $\%$ of results depict the concern of teachers towards tolerating and bearing the unhealthy attitude of the pupil, which might be the result of some insight of training as the 16 teachers also indicate the often-tried strategy of tolerance. But what would be the reaction of 02 and 05 teachers, might cause unhealthy consequences on pupil.

\section{Interviews}

The interviews focused on gathering data about teachers' perceptions about their own emotional understanding, regulation and expression. The analyses of the interviews are as follows:

Is there any place for teachers' emotions and self-confidence in teaching?

All of the teachers had an interesting point of view to share. Out of 10 teachers, about half of the teachers depicted mixed emotions for teaching. The positive emotions like enjoyment and enthusiasm were the motivating factors they found towards teaching. In addition, respect towards students was considered to be an essential part of teaching. Only few of the teachers mentioned that there is no change in their behavior or dealing people, be it inside the classroom or outside their working hours.

As far as Negative emotions are concerned only few of the teachers said teaching was an obligatory duty and it had just happened. Some of them believed that the profession of teaching is very demanding and that they cannot cope up with the demands. Emotions of fear and nervousness towards teaching were mentioned only "rarely".

The expertise in one's own field gives one confidence. Similarly, teachers felt quite confident because of their expertise in their own field. Some of the teachers found themselves incapable of having a command over the subject content they were teaching. As far as command over teaching skills was concerned almost all of the teachers believed that they were uncertain about their teaching skills and that they needed proper training and mentoring.

What could be the reasons of emotional suffering amongst teachers?

The teachers reported multiple reasons to this question. Overall, the causes could be divided into many categories, which are, family or personal, psychological, social, economic, biological, school administration, parents, incompetency to subject's mastery, promotion criteria, professional rivalry and failure to mark themselves in profession, shortage of time, salary etc.

During interviews it was observed that the teachers were not comfortable to discuss the private issues which were a hindrance in their profession of teaching. All of them avoided sharing anything as personal rather discussed the above-mentioned issues as 
general.

Do you think that the teachers could depict their suffering or distress to students?

Surprisingly, the teachers felt quite awkward about being personal and expressive in front of their students. They found it to be an ungraceful act. In addition, teachers found this question irrelevant in the context of emotional attitude and development. To this question, almost all of them replied that they this never express their wrath or distress to students.

Is a teacher model or a human being with emotions?

The respondents had different views to this question. The claimed that they have to act as models and avoid unpleasant situation, but at the same time they also stressed that they are humans too. One third of them opined that at times they do get angry due to stress or workload and things get out of control but then the fear of admin keeps the situation under control. Two third of them avoided any such commentary and claimed that they were perfectly under control in all distressed moods.

What are the long-term experiences that you confront by controlling suffering?

The respondents came up with different views. Some claimed that head ache was the common issue they have when distressed, while few of them claimed that low blood pressure and crying it out in private are the situations they face and do. Half of them said that they share it with peers, friends or family and half of them recommended praying and meditation.

What is your idea of teachers receiving Emotion related module in the academic training?

The teachers felt positive that they will be honed by this training. They felt that this will boost their confidence and it will help them take their students along with courage. The respondents used the words like "support", "encourage", "hone", "motivate" etc. for their professional skills. Some of the teachers reported that these trainings will help to cope in their work and they will become more relaxed by enjoying teaching more after receiving the emotional and psychological aspects of training.

\section{DISCUSSION}

The findings for the above study reveal that the teacher-student relationship towards emotional development of both teachers as well students is very important for carrying out the task of teaching successfully. Teachers of preschoolers are not less than a coach or an ideal to the emotional development, manifestation, understanding and regulation. The percentage of the data revealed that the teachers still need a lot to play their role as an effective teacher. The data also revealed the empathetic side of the children. The teachers could easily trace the incapability of any pupil towards expressing and 
regulating his/her emotions in social interaction with mates. Teachers can also enhance the relevant talk regarding emotions with pupil.

Knowledge of the teachers regarding the efficiency of relationship with pupil raises the quality of cognition, regulation, affective interactions and expectances. They needed to understand that the key to a successful and secure relationship with pupil leads to a more effective display of both negative and positive feelings whereas insecurity and uncomfortable relationships lead to exaggeration and falsification in display (Crittenden, 1992).

The findings also indicate that teachers' role as an instructor is greater and it has huge impact on students' behavior, happiness and success in class. The instructions by a teacher result in emotional development of preschoolers. It improves the outcomes of preschoolers. Furthermore, a secure and comfortable relationship leads to frankness in communication and negotiation skills. In contrast, insecure relations between teacherstudent lead to fear of rejection and coercive attitude. The security in a relationship helps regulate feelings, internal and in display, with the help of the teachers. The uncertainty in relationships leads to feelings of anger, anxiety and discomfort. The relation of a child with his teacher opens new vistas to venture. A negative relation of a teacher with a student eventually leads to a socially incompetent attitude of the child. Sometimes it may happens that the social relations do not fulfill the expectation of a child, therefore, he may experience a different and negative source of information and will lead into incorporation of the new info into his knowledge with the relations, which might result in damaging the relations and terms (Godwin, 2000).

The educational conduct and passionate character building, helps react in diverse ways under diverse social contexts. It entails that teachers have to realize the importance of their effectiveness and availability to the emotional needs of children's behavior in the classrooms. They help pupil grow stronger in emotional development. The child has to be taught that emotional behavior can be regulated and controlled only if the teachers are dependable and responsive. Teachers must also stay more welcoming, amenable and open to the reactions they receive from children. Relationships like this, lead children to develop a certain level of trust which is the ultimate achievement. Hartup says that under all conditions the terms of trust are to be witnessed in pressure (1989).

For the effectiveness of this relation, there are some methods which teachers can remember and implement. These include correctness of time, actions of warmth, apprehension of correctness, emotional administration and social problem resolving skills (Godwin, 2000). These practices are achievable via certain planning. Firstly, the teachers are required to spare some time in their daily lesson plans to assist children express their feelings. This will teach the pupil recognize their inner voice and have 
empathy for others. It will help them gain confidence in sharing, expressing, accepting and respecting the feelings of others. Eventually it helps in building relation of trust and openness with teachers and peers.

The teachers can also help children discuss their emotions. After parents, it is the teacher who can give an endorsement to child about expressing their emotions openly. Children need to vent their emotions so that they may not live with fears or burden of any kind. The main objective is to understand the relation between thinking and feeling. The way one feels or thinks lead to the way they will do.

The expressions of positive emotions can be inculcated in preschoolers by introducing activities which focuses on sharing, caring and respect for their peers. Activities like these can help in building strong personalities with traits like friendliness, openness and courage. In addition, teachers can also teach about regulating and controlling negative emotions. Teachers' reaction during child's negative emotional behavior is of importance. Denham (1998) states that a space in the corner can help a child to retrieve and calm down but this shall not be taken as a corner of punishment because the effect could be reversed with a negative interpretation.

The social problem-solving approach helps children grow more sensitive towards empathy to solve interpersonal problems. The objective is to promote an understanding among children how their actions affect others. The basic purpose is to enhance the need of communicating, compromising and interacting (Camras, 1980). The teacher should also leave students on their own and let them solve their disagreements without interrupting. The aim is to let them feel the boost of solving their problems on their own so that they may approach the teacher with the confidence that they have developed positive associate collaboration among themselves (Killen \& Turiel, 1991).

For a successful social life, the development of emotional feelings is of great importance. Teachers need to understand its significance and therefore they shall promote it. Emotional disturbances if not balanced at the preschoolers age can haunt the child for life time. Emotional behaviors have long term effects on their peer relations and personality building. Unsettled difficulties at early age led to behavior problems at middle childhood and later in life (Cicchetti et al., 1991). Studies show that children who comprehend what are emotions can not only express them well but can also control them. They are empathetic, better at communication as well as best communicators. They are also able to understand others emotional condition too.

The emotionally competent children who are open and flexible are regarded a better companion by peers and play partners. They are liked by their playmates. Hence, better guided and monitored emotional behavior of a child can lead to a better 
emotional behavior for a lifetime.

\section{CONCLUSION}

A quality learning environment depends upon the teacher. It is because of them and their perspectives which create an appropriate learning environment. The choice of content and activities depend upon the personal epistemologies and beliefs about emotional development. The element of expressiveness holds an equal amount of importance for both the teacher as well as the student. Teaching is a huge responsibility. It is not only about covering syllabus. The teachers need to comprehend, to their best of knowledge, the necessity of a most appropriate, composed and patient display of their emotional attitude towards understanding and regulating the emotional display of the children. The correctness of time, actions of warmth, and emotional administration are to be the resolving skills by the teachers. The child mentoring and guidance has long been talked of; teachers need the same kind of mentoring and counseling to vent their disturbed emotions. Teachers need their personal space some space as well as a break from being too robotic all the time. They needed to be given a margin from playing role model always.

\section{RECOMMENDATIONS}

The present study could be extended by adding the impact of emotions on teachers' performances. The study could also be extended by surveying and analyzing faculty development programs and highlighting the importance of emotional development of teachers while teaching.

The teachers being the integral part of an academic school needs mental sanity because health of the teacher can lead to a healthy environment. In order to establish and ensure quality learning environment, the teachers are suggested a self-evaluation as well as a counseling session for emotional development. In addition, sessions related to selfassessment will help them answer questions like why am I so sad?

The feelings of sadness and depression are important to be understood at the individual level. The ultimate remedy lies in expressing one's feelings to a trust worthy friend or colleague. Staying silent increases the depression. The School should take care of providing facilities of counseling and mentoring to both teachers as well as students. Visiting a Psychologist, Psychiatrist, or Therapist could also be a remedy for depression before it overtakes one's normality. A healthy teacher in mind and body can lead and come up with a best class. A self-contented teacher is more heuristic in his approach. They communicate effectively and can think of multiple ways to solve the emotional problems of the children as a moral duty.

Along with developing preschoolers' emotional needs, who will play Sherlock holmes 
for the teachers to solve their mysteries? Teachers are neither appreciated for the effort they put in bringing positive emotional development in preschoolers nor are they promoted for it. The teachers should be appreciated for their efforts as in the face of adversaries they still manage to give their best. Psychological confrontment to emotions has to be made an essential module of teachers training.

\section{REFERENCES}

Borghans, L., A.L. Duckworth, J.J. Heckman, and B. Ter Weel. (2008). The Economics and Psychology of Personality Traits. Journal of Human Resources, 43 (4), pp. 972-1059.

Brackett, M.A., Reyes, M.R., Rivers, S.E., Elbertson, N. A., Salovey, P. (2011). Classroom emotional climate, teacher affiliation and student conduct. Journal of class room interaction, 46 (1), pp. 27-36

Camras, L. A. (1980). Children's understanding of facial expressions used during conflict encounters. Child Development, 51, 879-885.

Cicchetti, D., Ganiban, J., \& Barnett, D. (1991). Contributions from the study of high-risk populations to understanding the development of emotion regulation. In J. Garber \& K.A. Dodge (Eds.), The development of emotion regulation and dysregulation (pp. 1548). Cambridge, UK: Cambridge University Press.

Chetty, R., J.N. Friedman, N. Hilger, E. Saez, D. Schanzenbach, and D. Yagan. (2011). How Does Your Kindergarten Classroom Affect Your Earnings? Evidence from Project STAR. Quarterly Journal of Economics, 126 (4), pp. 1593-1660.

Crittenden, P.M. (1992). Quality of attachment in the preschool years. Development and Psychopathology, 4, 209-241.

Denham, S.S. (1998). Emotional development in young children. New York:Guilford.

Duckworth, A.L., C. Peterson, M.D. Matthews, and D.R. Kelly. (2007). Grit: Perseverance and Passion for Long-Term Goals. Journal of Personality and Social Psychology, 92, 6, pp. 1087-1101.

Duckworth, A.L., and D.S. Yeager. (2015). Measurement Matters: Assessing Personal Qualities Other than Cognitive Ability for Educational Purposes. Educational Researcher, (44)4, pp. 237-251.

Eisenberg. N., Fabes, R.A., Miller, P. A., Shell, R., Shea, C., \& Mayplumlee, T. (1990). Preschoolers vicarious emotional responding nd their situational and dispositional prosocial behavior. Merrill-Palmer Quarterly, 36, 507-528.

Ekman, P., \& Friesen, W. V. (1975). Unmasking the face. Englewood Cliffs, NJ: Prentice Hall. Farrington, C.A., M. Roderick, E. Allensworth, J. Nagaoka, T.S. Keyes, D.W. Johnson, and N.O. Beechum. (2012). Teaching Adolescents to Become Learners: The Role of NonCognitive Factors in Shaping School Performance, a Critical Literature Review. Chicago: University of Chicago Consortium on Chicago School Reform.

Godwin, S. A. (2000). Promoting the emotional development of Preschoolers. Early Childhood Education Journal, 28 (2), pp. 79-84.

Halberstadt, A. G. (1991). Socialization of expressiveness: Family influences in particular and a model in general. In R.S. Feldman \& S. Rime (Eds.), Fundamentals of emotional 

expressiveness (pp. 106-162). Cambridge University Press.

Hargreaves, A. (2000). Mixed emotions: Teachers' perceptions of their interactions with students. Teaching and teacher education, 16(8), 811-826.

Hartup, W. W. (1989). Social relationship and their developmental significance. American Psychologist, 44, 120-126.

Jackson, C.K. (2012). Non-Cognitive Ability, Test Scores, and Teacher Quality: Evidence from Ninth Grade Teachers in North Carolina. NBER Working Paper No. 18624. Cambridge, MA: National Bureau for Economic Research.

Koedel, C. (2008). Teacher Quality and Dropout Outcomes in a Large, Urban School District. Journal of Urban Economics, 64 (3), pp. 560-572.

Moffitt, T.E., L. Arseneault, D. Belsky, N. Dickson, R.J. Hancox, H. Harrington, R. Houts, R. Poulton, B.W. Roberts, and S. Ross. (2011). A Gradient of Childhood Self-Control Predicts Health, Wealth, and Public Safety. Proceedings of the National Academy of Sciences, 108 (7), pp. 2693-2698.

Mueller, G., and E. Plug. (2006). Estimating the Effect of Personality on Male and Female Earnings. Industrial \& Labor Relations Review, 60 (1), pp. 3-22.

Postareff, L., \& Lindblom-Ylänne, Sari. (2011). Emotions and confidence within teaching in higher education. Studies in Higher Education, 36(7), pp. 799-813.

Robinson, J. L., Emde, R. N., \& Korfmacher, J. (1997). Integrating an emotional regulation perspective in a program of prenatal and early childhood visitation. Journal of community Psychology, 25, 59-75.

Roorda, D.L., H.M. Koomen, J.L. Spilt, and F.J. Oort. (2011). The Influence of Affective TeacherStudent Relationships on Students' School Engagement and Achievement: A Meta-Analytic Approach. Review of Educational Research, 81 (4), pp. 493-529.

Ruzek, E.A., T. Domina, A.M. Conley, G.J. Duncan, and S.A. Karabenick. (2014). Using Value-Added Models to Measure Teacher Effects on Students' Motivation and Achievement. The Journal of Early Adolescence, 35, nos. 5-6, pp. 852-882.

Sroufe, L. A. (1997). Emotional development: The organization of emotional life in the early years. Cambridge, UK: Cambridge University Press.

Vaughn, B., Stevenson-Hinde, J., Waters, E., Kutsaftis, A., Lefever, G., Shouldice, A., Trudel, M., \& Belsky, J. (1992). Attachment security and temperament in infancy and early childhood: Some conceptual clarifications. Development Psychology, 28, 463-473.

Willson, I.A. (1973). Changes in Mean Levels of Thinking in Grades 1-8 Through Use of an Interaction Analysis System Based on Bloom's Taxonomy. Journal of Educational Research, 66 (9), pp. 423-429. 